\title{
Pemanfaatan Ampas Tahu dan Kayambang dengan Pupuk Kandang Ayam sebagai Amelioran dalam Budidaya Jagung Manis (Zea mays saccharata Sturt) di Tanah Gambut
}

\begin{abstract}
The Using of Toffu (Soybean production) Waste and Kayambang with Chicken Manure as The Ameliorant for Sweet Corn (Zea mays saccharataSturt) Cultivation in Peat Soil.
\end{abstract}

\author{
Yusanti Mantuh \\ Universitas Kristen Palangka Raya
}

yusantimantuh@gmail.com

\begin{abstract}
This research aims were to find the effect of giving Toffu (Soybean production) Waste and Kayambang with Chicken Manure as The Ameliorant on Growth and Yield of Sweet Corn (Zea mays saccharataSturt) Cultivation in Peat Soil. Then, to find the effect of giving both of Toffu Waste and Kayambang on Growth and Yield of Sweet Corn Cultivation in Peat Soil. Also to find the effect of giving Chicken Manure only on Growth and Yield of Sweet Corn Cultivation in Peat Soil. Moreover, this research design was a field experiment design that was arranged by using Randomized Block Design (RBD) with 2 (two) treatment factors and 3 (three) repetitions. In addition, the factors in this research were: first factor (A) were toffu waste and kayambang with 5 levels, those we:A0 (Without added bytoffuwaste and kayambang), A1 (Toffu waste 5 ton acre ${ }^{-1}$ ), A2 (Toffu waste 10 ton acre ${ }^{-1}$ ), A3 (kayambang 5 ton $\left.\mathrm{acre}^{-1}\right)$, and A4 (kayambang 10 ton acre ${ }^{-1}$ ). While the second factors (B) were chicken manure with 3 levels, those were B0 (without chicken manure), B1 (chicken manure 5 ton $\mathrm{acre}^{-1}$ ), and B2 (chicken manure 10 ton acre ${ }^{-1}$ ). Furthermore, the result of this research showed that the interaction of giving Toffu (Soybean production) Waste and Kayambang with Chicken Manure as The Ameliorant gave the real effect to the ratio of between shoot and root, also the yield of Sweet Corn (Zea mays saccharataSturt), especially in the weight of sweet corn cob with and without its cover, also the diameter of the cob. As the result, the using of toffu waste and kayambang as ameliorant showed high effect to the plant. While the using of chicken manure gave effects to the vegetation growth (plant high, leaves weight, shoot dry weight, roots dried weight) and to the lenght of the sweet corn cob in the harvest time.
\end{abstract}

Keywords : Toffu (Soybean production) Waste, Kayambang, Chicken Manure, Ameliorant

\begin{abstract}
Abstrak
Penelitian ini bertujuan untuk mengetahui interaksi pemberian ampas tahu dan kayambang dengan pupuk kandang ayam sebagai amelioran terhadap pertumbuhan dan hasil jagung manis di tanah gambut, untuk mengetahui pengaruh pemberian ampas tahu dan kayambang terhadap pertumbuhan dan hasil jagung manis di tanah gambut dan untuk mengetahui pengaruh pemberian pupuk kandang ayam terhadap pertumbuhan dan hasil jagung manis di tanah gambut.Penelitian ini berupa percobaan lapangan yang disusun menggunakan Rancangan Acak Kelompok (RAK) faktorial dengan 2 (dua) faktor perlakuan dan 3 (tiga) ulangan. Adapun yang menjadi faktor dalam penelitian ini adalah : faktor
\end{abstract}


pertama (A) adalah ampas tahu dan kayambang dengan 5 taraf, yakni : A0 (tanpa penambahan ampas tahu dan kayambang), A1 (ampas tahu 5 t.ha $^{-1}$ ), A2 (ampas tahu 10 t.ha $^{-1}$ ), A3 (kayambang 5 t.ha $^{-1}$ ) dan A4 (kayambang 10 t.ha $^{-1}$ ), sedangkan faktor kedua (B) adalah pupuk kandang ayam dengan 3 taraf yakni : B0 (tanpa pupuk kandang), B1 (pupuk kandang ayam 5 t.ha ${ }^{-1}$ ) dan B2 (pupuk kandang ayam 10 t.ha $^{-1}$ ). Hasil penelitian menunjukkan bahwa Interaksi pemberian ampas tahu dan kayambang dengan pupuk kandang ayam sebagai amelioran menunjukkan pengaruh terhadap rasio tajuk dan akar dan hasil tanaman jagung manis saat panen, yakni berat tongkol dengan klobot, berat tongkol tanpa klobot dan diameter tongkol. Pemberian ampas tahu dan kayambang sebagai amelioran menunjukkan pengaruh terhadap tinggi tanaman. Pemberian pupuk kandang ayam sebagai amelioran menunjukkan pengaruh terhadap pertumbuhan vegetatif (tinggi tanaman, luas daun, berat kering tajuk, berat kering akar) dan pada panjang tongkol jagung manis saat panen.

Kata kunci : Ampas Tahu, Kayambang, Pupuk Kandang Ayam, Amelioran.

\section{PENDAHULUAN}

Jagung manis (Zea mays saccharata Sturt) merupakan salah satu jenis jagung yang saat ini sangat digemari, terutama karena rasanya yang enak dan manis, mengandung karbohidrat yang tinggi serta kandungan protein dan lemaknya yang rendah, mempunyai umur tanaman yang singkat dibandingkan dengan jagung jenis lainnya.

Masalah utama dalam pemanfaatan tanah gambut adalah terbatasnya kemampuan fisil dan kimia tanah, seperti tingkat kematangan, kemasaman tanah atau rendahnya $\mathrm{pH}(3,0$ - 4,5), rendahnya ketersediaan unsur $\mathrm{N}$, $\mathrm{P}, \mathrm{K}, \mathrm{Ca}$ dan unsur-unsur mikro. Karena sifat fisik dan kimia gambut yang marginal merupakan salah satu faktor pembatas, sehingga membutuhkan masukan unsur hara tinggi untuk meningkatkan produktivitas usaha budidaya tanaman pertanian di tanah gambut (Radjagukguk dan Setiadi, 1989). Salah satu cara untuk memperbaiki dan meminimalkan faktor pembatas tersebut melalui pemberian amelioran berupa bahan organik/anorganik. Namun demikian, perbaikan itu tidak hanya dengan aplikasi satu jenis amelioran saja, tetapi perlu perpaduan dari beberapa amelioran yang saling bersinergi dan dapat dikombinasikan untuk memperbaiki kendala budidaya pada tanah gambut. Menurut Najiyati, dkk., (2005), penggunaan amelioran secara tunggal belum mampu meningkatkan hasil tanaman secara nyata, hal ini disebabkan masing-masing amelioran memiliki kelebihan dan kekurangan. Selain itu, penggunaan amelioran secara tunggal akan memerlukan dosis yang cukup tinggi. 
Di kota Palangka Raya, ampas tahu yang dihasilkan dari industri pengolahan tahu, belum dimanfaatkan sebagai penyubur tanah, padahal ampas tahu tersebut masih mengandung unsur hara, sehingga memberi indikasi bahwa ampas tahu dapat dijadikan alternatif untuk meningkatkan ketersediaan unsur hara bagi tanaman. Kayambang merupakan tumbuhan yang dianggap sebagai limbah perairan (gulma air) yang pertumbuhannya cepat dan mudah melapuk serta kaya akan unsur hara, sehingga dapat dijadikan sebagai pupuk organik untuk meningkatkan kesuburan dan memperbaiki sifat-sifat tanah gambut. Pemberian pupuk kandang ayam selain sebagai amelioran, juga berperan sebagai dekomposer untuk mempercepat proses dekomposisi ampas tahu dan kayambang yang diberikan dalam bentuk segar (tidak dalam bentuk kompos),sehingga dapat memperbaiki sifat fisik dan kimia gambut. Memperhatikan terbatasnya kemampuan tanah gambut untuk menunjang pertumbuhan tanaman dan melihat ketersediaan berupa ampas tahu, kayambang dan kotoran ayam di Kota Palangka Raya yang dianggap mampu memperbaiki tanah gambut, maka perlu dilakukan penelitian untuk menggali potensi sumber amelioran yang belum dimanfaatkan dengan baik yang ada disekitar kita, sehingga penggunaan pupuk anorganik dapat berkurang dan dapat meningkatkan pertumbuhanan dan hasil tanaman di tanah gambut.

\section{TUJUAN PENELITIAN}

1. Mengetahui interaksi pemberian ampas tahu dan kayambang dengan pupuk kandang ayam sebagai amelioran terhadap pertumbuhan dan hasil jagung manis di tanah gambut.

2. Mengetahui pengaruh pemberian ampas tahu dan kayambang terhadap pertumbuhan dan hasil jagung manis di tanah gambut.

3. Mengetahui pengaruh pemberian pupuk kandang ayam terhadap pertumbuhan dan hasil jagung manis di tanah gambut.

\section{METODE PENELITIAN}

\section{Alat dan Bahan}

Alat-alat yang digunakan dalam penelitian ini adalah cangkul, parang, sekop, garu tanah, alat tulis menulis, amplop, pengaris/meteran untuk mengukur tinggi tanaman, timbangan manual, neraca analitik, gunting, jangka sorong, oven, kamera, alat tugal, tali rapia, pisau dan alat bantu lainnya yang dapat menunjang pelaksanaan penelitian. Bahan yang digunakan dalam penelitian ini adalah ampas tahu padat, tumbuhan kayambang dan pupuk kandang ayam, benih jagung manis Sari Sweet F1, 
dolomit, furadan 3G, pestisida, pupuk Urea, SP-36 dan KCl.

\section{Metode Penelitian}

Penelitian ini berupa percobaan lapangan yang disusun menggunakan Rancangan Acak Kelompok (RAK) faktorial dengan 2 (dua) faktor perlakuan dan 3 (tiga) ulangan. Adapun yang menjadi faktor dalam penelitian ini adalah : faktor pertama (A) adalah ampas tahu dan kayambang dengan 5 taraf, yakni : A0 (tanpa penambahan ampas tahu dan kayambang), A1 (ampas tahu 5 t.ha $^{-1}$ ), A2 (ampas tahu 10 t.ha ${ }^{-1}$ ), A3 (kayambang 5 t.ha $^{-1}$ ) dan A4 (kayambang 10 t.ha $^{-1}$ ), sedangkan faktor kedua (B) adalah pupuk kandang ayam dengan 3 taraf yakni : B0 (tanpa pupuk kandang), B1 (pupuk kandang ayam 5 t.ha $^{-1}$ ) dan B2 (pupuk kandang ayam 10 t.ha ${ }^{-1}$ ).

\section{Pelaksanaan Penelitian}

Persiapan lahan, penanaman, pemupukan, pemeliharaan, panen dan pengamatan. Ampas tahu, kayambang dan pupuk kandang ayam dikeringangikan selama 14 hari. Pengamatan : pertumbuhan tanaman (tinggi tanaman, luas daun, berat kering tajuk, berat kering akar, rasio tajuk dan akar). Hasil tanaman Jagung Manis : berat tongkol dengan klobot, berat tongkol tanpa klobot, panjang tongkol, diameter tongkol.

Analisis data : menggunakan analisis ragam (uji F). Apabila hasil uji F menunjukkan pengaruh nyata atau sangat nyata maka dilakukan analisis lanjutan dengan Uji Beda Jarak Nyata Duncan (BJND) dengan taraf 5\%.

\section{HASIL DAN PEMBAHASAN}

\section{Tinggi Tanaman}

Tabel 1. Rata-rata tinggi tanaman (cm) pada umur 2 - 6 MST

\begin{tabular}{|c|c|c|c|c|c|c|}
\hline \multirow{2}{*}{$\begin{array}{c}\text { Pemberian } \\
\text { pupuk kandang } \\
\text { ayam (faktor B) }\end{array}$} & \multicolumn{5}{|c|}{ Pemberian ampas tahu dan kayambang (faktor A) } & \multirow{2}{*}{$\begin{array}{l}\text { Rata-rata } \\
\text { (B) }\end{array}$} \\
\hline & A0 & A1 & A2 & A3 & A4 & \\
\hline \multicolumn{7}{|c|}{2 MST } \\
\hline B0 & 17,33 & 25,83 & 21,43 & 20,83 & 21,67 & 21,42 \\
\hline B1 & 22,67 & 26,33 & 24,33 & 23,17 & 22,00 & 23,70 \\
\hline $\mathrm{B} 2$ & 23,34 & 28,00 & 22,17 & 22,00 & 21,50 & 24,22 \\
\hline Rata-rata $(\mathrm{A})$ & $21,14 \mathrm{a}$ & $26,72 \mathrm{~b}$ & $22,64 \mathrm{a}$ & $23,33 \mathrm{ab}$ & $21,72 \mathrm{a}$ & - \\
\hline \multicolumn{7}{|c|}{3 MST } \\
\hline B0 & 33,67 & 36,67 & 40,00 & 36,43 & 33,50 & $36,05 \mathrm{a}$ \\
\hline B1 & 44,67 & 52,63 & 47,17 & 43,07 & 37,50 & $45,01 \mathrm{~b}$ \\
\hline B2 & 53,33 & 41,00 & 44,73 & 49,00 & 46,13 & $46,84 \mathrm{~b}$ \\
\hline Rata-rata $(\mathrm{A})$ & 43,89 & 43,43 & 43,97 & 42,83 & 39,04 & - \\
\hline \multicolumn{7}{|c|}{4 MST } \\
\hline B0 & 73,27 & 80,33 & 63,80 & 63,20 & 57,93 & $67,71 \mathrm{a}$ \\
\hline
\end{tabular}




\begin{tabular}{|c|c|c|c|c|c|c|}
\hline B1 & 76,60 & 77,50 & 69,27 & 80,80 & 72,80 & $75,39 \mathrm{ab}$ \\
B2 & 71,83 & 84,50 & 82,30 & 85,77 & 87,33 & $82,35 \mathrm{~b}$ \\
\hline Rata-rata (A) & 73,90 & 80,78 & 71,79 & 76,59 & 72,69 & - \\
\hline \multicolumn{7}{|c|}{$\mathbf{5}$ MST } \\
\hline B0 & 115,67 & 122,67 & 111,00 & 96,10 & 107,33 & $110,55 \mathrm{a}$ \\
B1 & 140,67 & 132,33 & 138,33 & 136,33 & 140,00 & $137,53 \mathrm{~b}$ \\
B2 & 123,67 & 155,67 & 109,67 & 153,00 & 146,33 & $137,67 \mathrm{~b}$ \\
\hline Rata-rata (A) & 126,67 & 136,89 & 119,67 & 128,48 & 131,22 & - \\
\hline \multicolumn{7}{|c|}{ 6 MST } \\
\hline B0 & 124,67 & 164,33 & 156,00 & 112,00 & 142,33 & $139,87 \mathrm{a}$ \\
B1 & 182,67 & 175,67 & 194,00 & 164,33 & 202,00 & $183,73 \mathrm{~b}$ \\
B2 & 151,00 & 186,67 & 168,67 & 212,67 & 194,00 & $182,60 \mathrm{~b}$ \\
\hline Rata-rata (A) & 152,78 & 175,56 & 172,89 & 163,00 & 179,44 & - \\
\hline
\end{tabular}

Keterangan : Angka yang diikuti huruf yang sama pada kolom atau baris dan umur pengamatan yang sama pada masing-masing perlakuan berarti tidak berbeda pada uji BJND 5\%

Hasil analisis ragam menunjukkan bahwa interaksi pemberian ampas tahu dan kayambang dengan pupuk kandang ayam tidak berpengaruh terhadap tinggi tanaman pada semua umur pengamatan, tetapi pemberian pupuk kandang ayam berpengaruh nyata pada umur 4 MST dan sangat nyata pada umur 3, 5 dan 6 MST, sedangkan pemberian ampas tahu dan kayambang menunjukkan pengaruh nyata pada umur 2 MST. Rata-rata tinggi tamanan umur 2-6 MST disajikan Tabel 1.

Pertumbuhan tinggi tanaman jagung meningkat seiring umur pengamatan, dimana pemberian pupuk kandang ayam baik pada perlakuan B1 maupun B2 memperlihatkan pertumbuhan tinggi tanaman jagung yang lebih baik dibandingkan perlakuan B0. Hal ini diduga karena pupuk kandang ayam mampu memperbaiki kesuburan tanah gambut, sehingga dapat meningkatkan ketersediaan unsur hara $\mathrm{N}$, $\mathrm{P}$ dan $\mathrm{K}$ yang diperlukan untuk pertumbuhan tanaman. Lingga dan Marsono (2010) menyatakan bahwa unsur nitrogen (N) sangat penting untuk pertumbuhan vegetatif tanaman karena dapat merangsang petumbuhan secara keseluruhan, khususnya batang, cabang dan daun. Unsur fospor (P), menurut Rosmarkam dan Yuwono (2002) berperan untuk pembentukan sejumlah protein tertentu, berperan dalam fotosintesis dan respirasi, sehingga sangat penting untuk pertumbuhan tanaman keseluruhan. Unsur kalium (K), menurut Sarief (1989) merupakan salah satu unsur hara yang sangat berperan dalam pertumbuhan tinggi tanaman.

\section{Luas Daun}

Hasil analisis ragam menunjukkan bahwa interaksi pemberian ampas tahu dan kayambang dengan pupuk kandang ayam tidak berpengaruh terhadap luas daun pada semua umur pengamatan, tetapi pemberian pupuk kandang ayam berpengaruh nyata 
pada umur 4 MST dan sangat nyata pada umur 3 dan 5 MST. Rata-rata luas daun pada umur 3, 4 dan 5 MST disajikan pada Tabel 2.

Tabel 2. Rata-rata luas daun $\left(\mathrm{cm}^{2}\right)$ pada umur 3- 5 MST

\begin{tabular}{|c|c|c|c|c|c|c|}
\hline \multirow{2}{*}{$\begin{array}{c}\text { Pemberian } \\
\text { pupuk kandang } \\
\text { ayam (faktor B) }\end{array}$} & \multicolumn{5}{|c|}{ Pemberian ampas tahu dan kayambang (faktor A) } & \multirow{2}{*}{$\begin{array}{l}\text { Rata-rata } \\
\text { (B) }\end{array}$} \\
\hline & A0 & A1 & A2 & A3 & A4 & \\
\hline \multicolumn{7}{|c|}{3 MST } \\
\hline B0 & 64,71 & 95,37 & 92,14 & 87,65 & 69,75 & $81,92 \mathrm{a}$ \\
\hline B1 & 126,77 & 111,95 & 111,06 & 102,37 & 98,04 & $110,04 \mathrm{~b}$ \\
\hline B2 & 104,24 & 93,32 & 111,56 & 116,55 & 133,65 & $111,86 \mathrm{~b}$ \\
\hline Rata-rata $(\mathrm{A})$ & 98,57 & 100,21 & 104,92 & 102,19 & 100,48 & - \\
\hline \multicolumn{7}{|c|}{4 MST } \\
\hline B0 & 172,66 & 190,90 & 161,67 & 160,58 & 107,48 & $158,66 \mathrm{a}$ \\
\hline B1 & 181,63 & 191,81 & 189,84 & 232,96 & 212,16 & $201,68 \mathrm{~b}$ \\
\hline B2 & 151,88 & 222,98 & 188,80 & 237,12 & 222,11 & $204,58 \mathrm{~b}$ \\
\hline Rata-rata (A) & 168,72 & 201,90 & 180,10 & 210,22 & 180,58 & - \\
\hline \multicolumn{7}{|c|}{5 MST } \\
\hline B0 & 270,71 & 272,26 & 286,45 & 257,48 & 274,83 & $272,35 \mathrm{a}$ \\
\hline B1 & 400,55 & 352,21 & 381,70 & 302,76 & 366,49 & $360,74 \mathrm{~b}$ \\
\hline $\mathrm{B} 2$ & 320,36 & 366,62 & 274,59 & 395,17 & 413,62 & $354,07 \mathrm{~b}$ \\
\hline Rata-rata (A) & 330,54 & 330,36 & 314,25 & 318,47 & 351,65 & - \\
\hline
\end{tabular}

Keterangan : Angka yang diikuti huruf yang sama pada kolom atau baris dan umur pengamatan yang sama pada masing-masing perlakuan berarti tidak berbeda pada uji BJND 5\%

Pemberian pupuk kandang ayam baik B1 maupun B2 dapat meningkatkan pertumbuhan luas daun yang lebih baik dibandingkan dengan perlakuan tanpa pupuk kandang ayam (B0). Menurut Gardner $d k k$., (1991), daun merupakan organ utama untuk menyerap cahaya dan untuk melakukan fotosintesis pada tanaman budidaya, dengan meningkatnya luas daun maka meningkat pula pernyerapan cahaya oleh daun. Tersedianya unsur nitrogen $(\mathrm{N})$ dari pupuk kandang ayam, diduga berperan langsung memacu pertumbuhan daun. Hal ini sesuai dengan pernyataan Lakitan (1996), bahwa pada saat pertumbuhan daun, diketahui tidak semua unsur hara diperlukan dan berperan langsung terhadap pertumbuhan daun. Unsur hara yang paling berpengaruh terhadap pertumbuhan dan perkembangan daun adalah nitrogen. Lebih lanjut Sutedjo (1991) menambahkan bahwa fungsi nitrogen $(\mathrm{N})$ antara lain untuk meningkatkan pertumbuhan daun, sehingga daun menjadi banyak, lebar dan warnanya hijau. Humphries dan Wheeler (1963 dalam Gardner dkk., 1991), menyatakan unsur nitrogen $(\mathrm{N})$ mempunyai pengaruh nyata terhadap perluasan daun terutama lebar dan luas daun. Pada fase vegetatif, tanaman banyak memerlukan karbohidrat untuk pembentukan jaringan, pembelahan, perpanjangan serta penebalan sel. Apabila 
hal ini berjalan dengan lancar, maka pertumbuhan daun akan berjalan dengan cepat. Selain nitrogen $(\mathrm{N})$, unsur fospor $(\mathrm{P})$ juga sangat dibutuhkan dalam kegiatan fotosintesis pada daun. Rosmarkam dan Yuwono (2002) menyatakan bahwa fospor dianggap sebagai kunci kehidupan karena berhubungan dengan senyawa energi sel (ATP) yang dibentuk pertama kali pada saat fosforilasi pada proses fotosintesis daun. Unsur fospor (P) sangat penting untuk kegiatan tersebut, sedangkan unsur $\mathrm{K}$ terlibat dalam mempengaruhi membuka dan menutupnya stomata pada daun, sehingga daun dapat mereduksi $\mathrm{CO}_{2}$ yang diperlukan untuk kegiatan fotosintesis.

\section{Berat Kering Tajuk}

Hasil analisis ragam menunjukkan bahwa interaksi pemberian ampas tahu dan kayambang dengan pupuk kandang ayam tidak berpengaruh terhadap berat kering tajuk pada semua umur pengamatan, tetapi pemberian pupuk kandang ayam berpengaruh nyata pada umur 4 MST dan sangat nyata pada umur 3, 5 dan 6 MST. Rata-rata berat kering tajuk pada umur 3, 5 dan 6 MST disajikan pada Tabel 3.

Peningkatan berat kering tajuk tanaman jagung yang diberi perlakuan pupuk kandang ayam baik itu B1 maupun B2 lebih baik dibandingkan dengan perlakuan tanpa pupuk kandang ayam (B0).
Hal ini diduga karena pemberian pupuk kandang ayam dapat menambah tersedianya unsur hara dalam tanah gambut. Peran unsur $\mathrm{N}$ dan $\mathrm{P}$ dalam pertumbuhan sangat penting. Kekurangan unsur $\mathrm{N}$ dan $\mathrm{P}$ akan menghambat pertumbuhan tanaman. Goldssworthy dan Fisher (1996) mengemukakan bahwa pertumbuhan tanaman terlihat dari perkembangan akar, daun dan batang yang berhubungan dengan proses pembelahan sel atau pembentukan jaringan yang terlihat melalui bobot kering tanaman (bagian tajuk dan akar). Lingga dan Marsono (2010), menambahkan bahwa unsur nitrogen $(\mathrm{N})$ diperlukan oleh tanaman untuk merangsang pertumbuhan secara keseluruhan khususnya batang dan membantu pembentukan klorofil yang berguna dalam proses fotosintesis. Makin tinggi nitrogen yang tersedia bagi tanaman, maka makin banyak pula pertumbuhan batang, tunas dan daun pada tanaman. Menurut Lakitan (1996), nitrogen merupakan penyusun dari banyak senyawa seperti asam amino yang diperlukan dalam pembentukan atau pertumbuhan bagianbagian vegetatif seperti batang, daun, dan akar. Unsur nitrogen yang tersedia lebih banyak mengakibatkan daun dapat tumbuh lebih lebar dan hijau, sehingga proses fotosintesis dapat berlangsung dengan baik. 
Tabel 3. Rata-rata berat kering tajuk (gram) pada umur 3, 5 dan 6 MST

\begin{tabular}{|c|c|c|c|c|c|c|}
\hline \multirow{2}{*}{$\begin{array}{c}\text { Pemberian } \\
\text { pupuk kandang } \\
\text { ayam (faktor B) }\end{array}$} & Pemberian ampas tahu dan kayambang (faktor A) & \multirow{2}{*}{$\begin{array}{c}\text { Rata-rata } \\
\text { (B) }\end{array}$} \\
\hline \multicolumn{7}{|c|}{ A0 MST } \\
\hline B0 & 1,4136 & 2,3064 & 1,8599 & 1,6453 & 1,4391 & 1,7329 a \\
B1 & 2,9123 & 4,6229 & 3,5578 & 2,2566 & 2,1529 & 3,1005 b \\
B2 & 3,3690 & 1,8874 & 3,0700 & 3,9809 & 3,9826 & 3,2580 b \\
\hline Rata-rata (A) & 2,5650 & 2,9389 & 2,8292 & 2,6276 & 2,5249 & \\
\hline \multicolumn{7}{|c|}{ 4 MST } \\
\hline B0 & 8,4004 & 7,0080 & 5,6632 & 5,6400 & 4,0872 & 6,1589 a \\
B1 & 8,4163 & 9,0851 & 9,5286 & 9,2509 & 8,8108 & 9,0183 b \\
B2 & 7,4387 & 10,8058 & 8,2416 & 11,5567 & 9,4658 & 9,5017 b \\
\hline Rata-rata (A) & 8,0851 & 8,9663 & 7,8111 & 8,8159 & 7,4531 & - \\
\hline \multicolumn{7}{|c|}{5 MST } \\
\hline B0 & 14,9015 & 14,3540 & 15,5343 & 15,6898 & 16,2606 & 15,3480 a \\
B1 & 29,9251 & 19,2214 & 26,2736 & 20,3997 & 29,8471 & 25,1334 b \\
B2 & 23,3537 & 28,1804 & 12,4162 & 26,1733 & 29,1337 & 23,8515 b \\
\hline Rata-rata (A) & 22,7268 & 20,5853 & 18,0747 & 20,7543 & 25,0805 & - \\
\hline \multicolumn{7}{|c|}{ 6 MST } \\
\hline B0 & 22,8606 & 35,3374 & 37,9317 & 22,6226 & 31,8323 & 30,1169 a \\
B1 & 50,9756 & 45,6650 & 50,3874 & 46,0498 & 50,1817 & 48,6515 b \\
B2 & 36,6507 & 48,6766 & 35,9988 & 55,8890 & 48,6735 & 45,1777 b \\
\hline Rata-rata (A) & 36,8290 & 43,2263 & 41,4393 & 41,5205 & 43,5625 & - \\
\hline
\end{tabular}

Keterangan : Angka yang diikuti huruf yang sama pada kolom atau baris dan umur pengamatan yang sama pada masing-masing perlakuan berarti tidak berbeda pada uji BJND 5\%

\section{Berat Kering Akar}

Hasil analisis ragam menunjukkan bahwa interaksi pemberian ampas tahu dan kayambang dengan pupuk kandang ayam tidak berpengaruh terhadap berat kering tajuk pada semua umur pengamatan, tetapi pemberian pupuk kandang ayam berpengaruh nyata pada umur 3 dan 6 MST. Rata-rata berat kering akar pada umur 3 dan 6 MST disajikan pada Tabel 4.

Peningkatan berat kering akar tanaman jagung yang diberi perlakuan pupuk kandang ayam baik itu B1 maupun B2 lebih baik dibandingkan dengan perlakuan tanpa pupuk kandang ayam (B0).
Hal ini diduga karena pupuk kandang ayam dapat menyediakan media tanam (tanah gambut) yang baik, sehingga berdampak positif terhadap penyerapan unsur hara. Menurut Gardner dkk., 1991, bahwa akar merupakan organ vegetatif utama yang memasok air, mineral dan bahan-bahan penting untuk pertumbuhan tanaman, dengan kondisi tanah gambut yang baik, maka akar dapat berkembang dengan baik pula, karena akar membutuhkan unsur hara yang cukup untuk pertumbuhan dan perkembangannya. Apabila tanaman kekurangan unsur hara, terutama unsur $\mathrm{P}$ dapat menyebabkan terhambatnya 
perkembangan akar, dimana akar akan kecilkecil, sehingga akan mempengaruhi berat kering akar tanaman jagung manis (Sarief, 1989). Ditambahkan oleh Suseno (1974), apabila tanaman jagung kekurangan unsur hara $\mathrm{N}, \mathrm{P}$ dan $\mathrm{K}$ akan menyebabkan pertumbuhan tanaman terhambat, akar menjadi lemah dan jumlah akar akan berkurang, sehingga mempengaruhi berat kering akar.

Tabel 4. Rata-rata berat kering akar (gram) pada umur 3 dan 6 MST

\begin{tabular}{|c|c|c|c|c|c|c|}
\hline \multirow{2}{*}{$\begin{array}{c}\text { Pemberian } \\
\text { pupuk kandang } \\
\text { ayam (faktor B) }\end{array}$} & \multicolumn{5}{|c|}{ Pemberian ampas tahu dan kayambang (faktor A) } & \multirow{2}{*}{$\begin{array}{l}\text { Rata-rata } \\
\text { (B) }\end{array}$} \\
\hline & A0 & $\mathrm{A} 1$ & $\mathrm{~A} 2$ & A3 & A4 & \\
\hline \multicolumn{7}{|c|}{3 MST } \\
\hline B0 & 0,3191 & 0,7049 & 0,7771 & 0,5398 & 0,4963 & $0,5674 \mathrm{a}$ \\
\hline B1 & 0,8544 & 1,0704 & 1,0906 & 0,7143 & 0,8228 & $0,9105 \mathrm{~b}$ \\
\hline $\mathrm{B} 2$ & 1,4009 & 0,5888 & 0,7879 & 0,9866 & 1,4770 & $0,9824 \mathrm{~b}$ \\
\hline Rata-rata (A) & 0,8581 & 0,7880 & 0,8852 & 0,7505 & 0,7469 & - \\
\hline \multicolumn{7}{|c|}{6 MST } \\
\hline B0 & 9,3858 & 12,2468 & 22,8169 & 8,3469 & 16,0484 & $13,7690 \mathrm{a}$ \\
\hline B1 & 21,3345 & 25,2892 & 33,0738 & 20,3979 & 29,2487 & $25,8688 \mathrm{~b}$ \\
\hline $\mathrm{B} 2$ & 20,4063 & 24,0235 & 11,5102 & 24,7688 & 23,8910 & $20,9200 \mathrm{ab}$ \\
\hline Rata-rata (A) & 17,0422 & 20,5198 & 22,4670 & 17,8397 & 23,0627 & - \\
\hline
\end{tabular}

Keterangan : Angka yang diikuti huruf yang sama pada kolom atau baris dan umur pengamatan yang sama pada masing-masing perlakuan berarti tidak berbeda pada uji BJND 5\%

\section{Hasil Panen Jagung Manis}

Hasil analisis ragam menunjukkan bahwa interaksi pemberian ampas tahu dan kayambang dan pupuk kandang ayam (faktor $\mathrm{AB}$ ) berpengaruh nyata terhadap berat tongkol dengan klobot dan berat tongkol tanpa klobot dan sangat nyata terhadap diameter tongkol, sedangkan pemberian pupuk kandang ayam menunjukkan pengaruh sangat nyata terhadap panjang tongkol jagung manis. Rata-rata hasil panen jagung manis dapat dilihat pada Tabel 5.

Berdasarkan Tabel 5, terlihat bahwa interaksi ampas tahu dan kayambang dengan pupuk kandang ayam, yakni perlakuan
A3B2 menunjukkan berat tongkol dengan klobot dan berat tongkol tanpa klobot tertinggi seberat 312,30 gram dan 226,40 gram, sedangkan perlakuan A3B0 menunjukkan berat tongkol dengan klobot dan berat tongkol tanpa klobot terendah, yakni 168,60 gram dan 129,50 gram. Diameter tongkol tertinggi pada perlakuan A4B1 yakni sebesar $4,69 \mathrm{~cm}$, tetapi tidak berbeda dengan diameter tongkol pada perlakuan A3B2 yang mempunyai diameter tongkol sebesar 4,61 cm, sedangkan perlakuan A2B0 mempunyai diameter tongkol terendah, yakni $3,83 \mathrm{~cm}$. Interaksi pemberian kayambang $5 \mathrm{t} \mathrm{ha}^{-1}$ (A3) dengan pupuk kandang ayam $10 \mathrm{t} \mathrm{ha}^{-1}$ (B2) 
berpengaruh terhadap peningkatan hasil panen jagung manis. Hal ini diduga karena kayambang dan pupuk kandang ayam telah terdekomposisi, sehingga dapat menambah ketersediaan unsur hara pada tanah gambut. Unsur hara tersebut diserap oleh tanaman secara perlahan dan terus menerus selama masa pertumbuhan vegetatif sampai pertumbuhan generatif. Musnamar (2008) menyatakan bahwa pupuk organik termasuk dalam ke dalam pupuk slow release. Unsur hara yang terkandung dalam pupuk organik tersebut ada yang langsung tersedia dan ada yang tidak langsung tersedia bagi tanaman. Unsur hara yang tidak langsung tersedia bagi tanaman dengan bantuan mikroorganisme tanah/jasad renik, di dalam tanah akan diubah menjadi bentuk yang bisa diserap oleh tanaman melalui proses dekomposisi/pelapukan. Dari proses tersebut akan dihasilkan $\mathrm{CO}_{2}$, air dan mineral. Kemudian melalui mineralisasi unsur hara menjadi tersedia bagi tanaman.

Tabel 5. Rata-rata pengamatan hasil panen tanaman jagung manis

\begin{tabular}{|c|c|c|c|c|c|c|}
\hline \multirow{2}{*}{$\begin{array}{c}\text { Pemberian } \\
\text { pupuk kandang } \\
\text { ayam (faktor B) }\end{array}$} & \multicolumn{7}{c|}{ Pemberian ampas tahu dan kayambang (faktor A) } & \multirow{2}{*}{$\begin{array}{c}\text { Rata-rata } \\
\text { (B) }\end{array}$} \\
\hline \multicolumn{7}{|c|}{ Berat tongkol dengan klobot (gram) } \\
\hline B0 & $237,80 \mathrm{~b}$ & $237,50 \mathrm{~b}$ & $189,50 \mathrm{a}$ & $168,60 \mathrm{a}$ & $177,50 \mathrm{a}$ & 202,18 \\
B1 & $199,90 \mathrm{a}$ & $257,40 \mathrm{~d}$ & $249,80 \mathrm{~d}$ & $245,10 \mathrm{c}$ & $290,90 \mathrm{ef}$ & 248,62 \\
B2 & $247,50 \mathrm{c}$ & $251,40 \mathrm{~d}$ & $269,00 \mathrm{e}$ & $312,30 \mathrm{~g}$ & $294,10 \mathrm{f}$ & 274,86 \\
\hline Rata-rata (A) & 228,40 & 248,77 & 236,10 & 242,00 & 254,17 & - \\
\hline \multicolumn{7}{|c|}{ Berat tongkol tanpa klobot (gram) } \\
\hline B0 & $165,10 \mathrm{a}$ & $175,00 \mathrm{~b}$ & $136,30 \mathrm{a}$ & $129,50 \mathrm{a}$ & $130,20 \mathrm{a}$ & 147,22 \\
B1 & $155,00 \mathrm{a}$ & $191,40 \mathrm{c}$ & $187,20 \mathrm{c}$ & $180,10 \mathrm{~b}$ & $214,40 \mathrm{~d}$ & 185,62 \\
B2 & $181,40 \mathrm{~b}$ & $190,90 \mathrm{c}$ & $198,40 \mathrm{c}$ & $226,40 \mathrm{e}$ & $216,60 \mathrm{de}$ & 202,74 \\
\hline Rata-rata (A) & 167,17 & 185,77 & 173,97 & 178,67 & 187,07 & - \\
\hline \multicolumn{7}{|c|}{ Panjang tongkol (cm) } \\
\hline B0 & 18,00 & 18,00 & 17,00 & 16,40 & 16,20 & $17,12 \mathrm{a}$ \\
B1 & 16,80 & 17,90 & 18,10 & 17,50 & 18,60 & $17,78 \mathrm{ab}$ \\
B2 & 17,70 & 17,90 & 18,40 & 18,30 & 18,60 & $18,18 \mathrm{~b}$ \\
\hline Rata-rata (A) & 17,50 & 17,93 & 17,83 & 17,40 & 17,80 & - \\
\hline \multicolumn{7}{|c|}{ Diameter tongkol (cm) } \\
\hline B0 & $4,30 \mathrm{~b}$ & $4,33 \mathrm{~b}$ & $3,83 \mathrm{a}$ & $3,92 \mathrm{a}$ & $3,88 \mathrm{a}$ & 4,07 \\
B1 & $4,09 \mathrm{a}$ & $4,36 \mathrm{~b}$ & $4,38 \mathrm{~b}$ & $4,28 \mathrm{~b}$ & $4,69 \mathrm{~d}$ & 4,36 \\
B2 & $4,48 \mathrm{~b}$ & $4,40 \mathrm{~b}$ & $4,46 \mathrm{~b}$ & $4,61 \mathrm{~cd}$ & $4,41 \mathrm{~b}$ & 4,47 \\
\hline Rata-rata (A) & 4,29 & 4,36 & 4,22 & 4,27 & 4,33 & \\
\hline
\end{tabular}

Keterangan : Angka yang diikuti huruf yang sama pada kolom atau baris dan umur pengamatan yang sama pada masing-masing perlakuan berarti tidak berbeda pada uji BJND 5\%

Panjang tongkol jagung manis dipengaruhi oleh pemberian pupuk kandang ayam, dimana perlakuan B2 memiliki panjang tongkol tertinggi sebesar $18,18 \mathrm{~cm}$ dan berbeda dengan perlakuan B0 yang mempunyai panjang tongkol terendah 17,12 
$\mathrm{cm}$, tetapi tidak berbeda dengan perlakuan B1 yang mempunyai panjang tongkol sebesar 17,78 cm (Tabel 5). Panjang tongkol jagung manisyang diberi perlakuan pupuk kandang ayam baik itu B1 maupun B2 lebih baik dibandingkan dengan perlakuan tanpa pupuk kandang ayam (B0). Hal ini diduga karena pupuk kandang mampu menambah ketersediaan unsur hara dalam tanah, sehingga dapat menunjung periode pengisian biji. Kekurangan hara pada periode ini akan menyebabkan biji tidak berkembang penuh.

\section{KESIMPULAN DAN SARAN}

\section{Kesimpulan}

1. Interaksi pemberian ampas tahu dan kayambang dengan pupuk kandang ayam sebagai amelioran menunjukkanpengaruh terhadap rasio tajuk dan akar, dan hasil tanaman jagung manis saat panen, yakni berat tongkol dengan klobot, berat tongkol tanpa klobot dan diameter tongkol.

2. Pemberian ampas tahu dan kayambang sebagai amelioran menunjukkan pengaruh terhadap tinggi tanaman.

3. Pemberian pupuk kandang ayam sebagai amelioran menunjukkan pengaruh terhadap pertumbuhan vegetatif (tinggi tanaman, luas daun, berat kering tajuk, berat kering akar) dan pada panjang tongkol jagung manis saat panen.

\section{Saran}

1. Agar pertumbuhan dan hasil tanaman jagung manis di tanah gambut yang lebih baik, disarankan menggunakan kombinasi amelioran $5 \mathrm{t} \quad \mathrm{ha}^{-1}$ kayambang dan $10 \mathrm{t} \mathrm{ha}^{-1}$ pupuk kandang ayam.

2. Perlu dilakukan penelitian lebih lanjut mengenai pemanfaatan ampas tahu dan kayambang dengan pupuk kandang ayam sebagai amelioran dalam budidaya tanaman jagung manis di tanah gambut dengan menambahkan variabel kandungan hara dalam jaringan tanaman, analisis kandungan klorofil pada daun dan analisis kadar gula pada jagung manis yang dihasilkan.

\section{DAFTAR PUSTAKA}

Gardner, F., R. B. Pearce dan R. L., Mitchell. 1991. Fisiologi Tanaman Budidaya. Cetakan ke 1. Universitas Indonesia Press. Jakarta.

Goldssworthy, P. R dan N. M. Fisher. 1996. Fisiologi Tanaman Budidaya Trofik (Terjemahan : Tosari). Cetakan ke 1. Gadjah Mada University. Yogyakarta.

Lakitan, B., 1996. Fisiologi Pertumbuhan dan Perkembangan Tanaman. PT. Raja Grafindo Persada.

Lingga, $P$ dan Marsono. 2010. Petunjuk Penggunaan Pupuk. Cetakan ke 28. Penebar Swadaya. Jakarta.

Musnamar, E. I. 2008. Pupuk Organik Padat Pembuatan dan Aplikasi. Seri Agritekno. Cetakan ke 4. Penebar Swadaya. Jakarta.

Najiyati, S., Lili M., dan I Nyoman N. S. 2005. Panduan Pengelolaan Lahan Gambut untuk 
Pertanian Berkelanjutan. Proyek Climate Change, Forests and Peatlands in Indonesia. Wetlands Internasional-Indonasia Programmer dan Wildlife Habitat Canada. Bogor. Indonesia.

Radjagukguk, B. dan Setiadi, B. 1989. Strategi Pemanfaatan Gambut di Indonesia : Kasus Pertanian. p. 1-13. Proseding Seminar Tanah Gambut untuk Perluasan Pertanian. Fakultas Pertanian USU. Medan.
Rosmarkam, A. dan Yuwono. 2002. Ilmu Kesuburan Tanah. Kanisius. Yogyakarta.

Sarief, E. S. 1989. Kesuburan dan Pemupukan Tanah Pertanian. Pustaka Buana. Bandung.

Suseno, H. 1974. Fisiologi Tumbuhan Metabolisme Dasar. Departemen Pertanian IPB. Bogor 